\title{
The Future is Long-term: past and current directions in environmental archaeology
}

\section{Charlene Murphy \& Dorian Q Fuller Institute of Archaeology, University College London, UK}

A few years ago the popularization of the Paleodiet (or 'Caveman Diet' or 'Stone Age diet') created a great deal of public interest in eating like our hunter-gatherer ancestors. The media buzz shone light on one aspect of Environmental Archaeology, which provided among other things evidence for both diversity within and amongst the diets of past hunter-gatherers. As a network of sub-disciplines, Environmental Archaeology is poised to not only enrich archaeological interpretation but contribute archaeology's important perspective on the long-term legacy of human and environment interactions that have relevance for the future of our planet.

The importance of archaeology to broader environmental studies has been increasingly highlighted, mapping in time and space our "Used Planet" (Ellis et al 2013), testing and refining our understanding of how climate has influenced cultural change and adaptation (d'Alpoim Guedes et al 2016), and the role of humans transforming ecologies, not just at local but continental and even global levels (Boivin et al 2016). This article offers an overview of the historical development of the field and current directions in research, including both recent methodological diversification in Environmental Archaeology and growing application to fields beyond archaeology.

\section{Environmental Archaeology Matures}

Environmental Archaeology is a subfield of Archaeology, incorporating all aspects of how humans alter and affect the natural environment in the past, working largely through datasets that are not strictly speaking artefacts but remains of other organisms, soils and sediments, recovered primarily from sites of past human activity. Indeed, some scholars have preferred the term human palaeoecology to emphasize 
humanity's role in shaping the past environment. Research questions focus around connections between the environment and humans including aspects of diet, economy, daily life, and landuse.

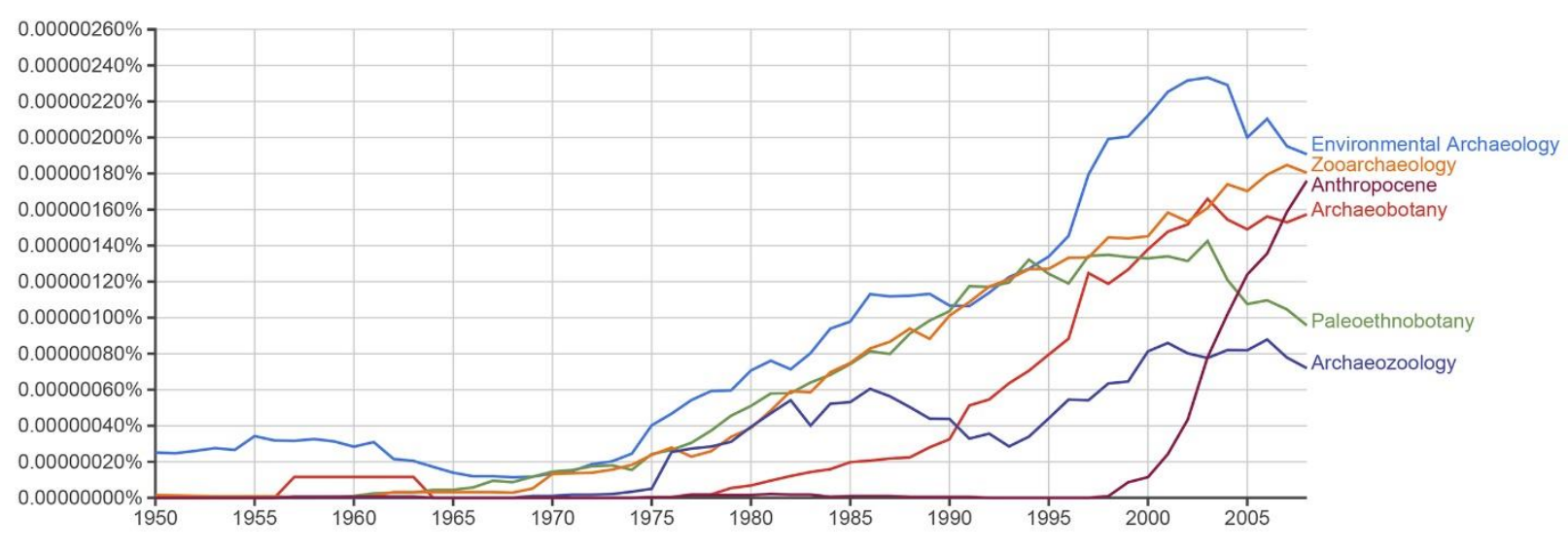

Figure 1: Frequency of terms related to Environmental Archaeology including Anthropocene in English language books published between 1950 and 2008, based on Google Books database, searched 30/12/2016 (https://books.google.com/ngrams).

Environmental archaeology emerged as a distinct discipline relatively recently, in the mid-twentieth century, i.e. over the course of ca. 65 years, and it has seen an expansion in the recognition of its research area (Fig. 1). Environmental archaeology can credit its beginnings to researchers looking beyond the boundaries of their disciplines into archaeology (Derevenski 2001, 115). Much of this research was carried out by scientists who worked on excavated materials given to them by archaeologists during their post-excavation period of analysis and write-up as "occasional scientistconsultants" phase (Fuller 2008). This was in full-swing in the 1950s, which also saw the first archaeological field projects that incorporated non-archaeologist scientists into explicitly interdisciplinary projects, such as the excavations at the British Mesolithic site of Star Carr (1949-1951), or the American field project at Jarmo (19481954), Iraq (see Trigger 1989, 268-269, 280). This general era saw the first appointment of geologists, zoologists or botanists into archaeology departments, who began to train the first generation of the new hybrid archaeological scientists, such as archaeobotanists or archaeozoologists in the 1960s-1970s. In North America this was seen as an extension into the archaeological past of ethnography focused on the recording of environmental use and perception of native peoples, such as through ethnobotany (Ford 2011). The 1960s and 1970s saw the first generation of specialists 
trained in and doing PhDs on environmental archaeology, i.e. the professionalization of the archaeological sciences.

The specializations of Environmental Archaeology can be said to have matured through the 1980s and 1990s, with increasing debates over methodological rigor and attention to the particular problems of assemblage formation (Fuller 2008). Although this can be regarded as the emergence of "self-critical" archaeological science (Fuller $2008,214)$, it is also a period, however, in which there were tendencies toward the stigmatization of environmental archaeology. Theoretical debates in archaeology, including Post-Processualism, raised critiques of positivism; this was part of wider suspicion of anthropological sub-disciplines most closely allied with the sciences. This led to calls for the results of archaeological science to be made more intelligible in terms of the social past. Nevertheless, there remained a tendency for environmental archaeologists to talk to themselves and debate the practical issues surrounding their datasets, separately from "mainstream" archaeology, leading to a sense of marginalization (Derevenski 2001). Nevertheless, there remained continued growth in the recognition that Environmental Archaeology should be incorporated into archaeological field research design and teaching at all levels (Derevenski 2001, 125). When DQ Fuller was an undergraduate in the early 1990s the excavation textbook he was assigned included no discussion of sampling or flotation for geoarchaeology, but today one would be hard-pressed to find a fieldwork manual without the inclusion of sampling for environmental archaeology.

We contend that Environmental Archaeology has entered a fourth phase, one in which it has a key role to play not just in holistic archaeological investigation but also in making archaeological results relevant to research on climate change, landscape ecology and conservation, human diet and more broadly Anthropocene studies. It is increasingly recognized that the long time horizon provided by archaeological evidence is important to many fields. Modern scientific studies, whether they are of community ecology, landuse sustainability, or influence of human activities on greenhouse gas emissions. Environmental Archaeology has much to add to this important debate alongside more traditional fields. As more archaeologists engage with research questions that are macro-regional, continental and even global through the comparison and compilation of ever larger datasets, Environmental Archaeology is well-placed to translate archaeological information for the Life and Earth Sciences. 


\section{The Anthropocene and Applied Environmental Archaeology}

The concept of the "Anthropocene" in which humans become the major driving force shaping Earth's ecosystems, atmosphere, and landforms is gaining increasing attention in discussions of human's evolutionary trajectory and how it should be defined (Ellis et al 2013). Recent scholarship has now demonstrated that humans have had an impact upon their environments for at least several thousand years, and "pristine" landscapes lacking human influence simply do not exist and have not existed for millennia (Boivin et al 2016). It is not just the case that humans have impacted their local environs and species in their immediate food chains, but also regional soils, and even potentially global climates. We live on a "Used Planet" (Ellis et al 2013) and understanding humanity's past impact on environmental use, stewardship, and resilience, may be more than mere background to current conservation efforts but key variables to intelligent planning. This raises questions about the ethical/moral responsibilities of Environmental Archaeologists. Archaeology needs to engage with a big picture view looking beyond the trench, site, and regional tradition.

Human influences are important to the understanding of landscape ecology, which is itself the long-term outcome of evolutionary processes (Ellis et al 2013). Ruddiman (2013) provides a parable of how sedimentologists working in the eastern U.S. in the 1950s formulated "natural laws" of sedimentology and hydrology, overlooking the fact that the streams they worked on had been influenced by deforestation, agriculture

and old mills from the $17^{\text {th }}$ to $19^{\text {th }}$ centuries. Millennia of prehistoric landuse prior to this must have similarly been forgotten. Environmental Archaeology is able to inform how landuse has shaped the land and biota, which in turn provides the basis for a "utilitarian archaeology" (Minnis 2014) that can inform land management decisions in the present, such as calls for "applied zooarchaeology" to the field of conservation biology (Lyman 2012).

\section{The challenge of crossing disciplines}

A forward looking Environmental Archaeology is arguably central to a realistic approach to archaeology's relevance to discussions of biological conservation and resource management. Nevertheless, despite the familiarity of environmental 
archaeologists with the methods and language of various environmental sciences, archaeology has tended to figure little in practical discourses on conservation biology (see Lyman 2012), agricultural diversity conservation (see Minnis 2014), or the longterm impact of human landuse on landcover and climate (see Ellis et al 2013). Yet, as Lyman (2012) notes, conservation biologists rarely heed the archaeological long-term, regarding such data as somehow imperfect, while Minnis (2014) notes that despite the fact that agricultural heritage is one of the most profound legacies of human prehistory, archaeobotanical evidence has featured little in discussions of agricultural planning. If the world is to move beyond the $20^{\text {th }}$ century " green revolution", which was about quantity (of a few species) to an "evergreen revolution" about land quality and health (Schwagerl 2014), the great diversity of agricultural experience and crop diversity only accessible through archaeology may prove important.

While some archaeologists call for the need to learn more of the aims and methods of fields like conservation biology (e.g. Lyman 2012), it remains rather uncommon that practioners in other fields call for training in archaeology. This highlights the importance of cross-disciplinary collaboration in the compilation and comparison of datasets derived from different research traditions and timescales (e.g. Ellis et al 2013). Practical challenges remain, including terminological misunderstandings, divergences in publication cultures and differing views on the impact of research (Izdebski et al 2016). Rather than cross-disciplinary consultations taking place at the publication stage, there is the need for more genuinely equal involvement in project design from the beginning.

\section{Environmental Archaeology expanding: new methods and big data}

Environmental Archaeologists continue to expand their toolkit, making new datasets and potentially new research questions part of archaeology. Like other scientific fields Environmental Archaeology moves toward ever smaller scales of resolution. In particular, relatively new areas of research include a range of isotopic analyses, computerized tomography (CT) scanning technology, and ancient biomolecules, not just DNA but proteins, such as ZooMS (ZooArchaeology by Mass Spectrometry) that has a high potential to separate taxa previously inseparable by traditional methods. There is a broadening range of microfossils under investigation from the traditional pollen grains and phytoliths (silica impression of plant structures), to starch grains, diatoms (single-celled alga with silica cell wall), and various other microscopic 
organisms. It has to be acknowledged that these new techniques often come with methodological problems, and continuing debates over the reliability of both identification and antiquity of starch grains provides one example (e.g. Barton and Torrence 2015). At the same time, traditional datasets like bones and charred seeds, have seen continued developments in new methods, such as the application of geometric morphometrics for identification, or functional morphology approaches to plant ecology.

Environmental Archaeology is part of what Bevan (2015) has dubbed the "big data revolution" in archaeology. Such databases of archaeological plant and animal data are becoming increasingly available resources for revealing large scale patterns and processes over space and time (e.g. see Journal of Open Archaeology Data). Such approaches allow the integration of data in new ways, such as converting large quantities of radiocarbon dates into demographic proxies, which can be used in a multiproxy approach with data such as the age profiles of skeletal populations (e.g. Downey et al 2014). Such statistical patterns in the occurrence taxa and/or populations in the past provide a new basis for exploring potential correlations with climatic change and variable responses in different regions or cultural traditions. In addition, developments in modelling climatic variability across space and time, emphasizing variability as much as averages, provide a new framework in which archaeological evidence for the occurrence of taxa in the past can be used to test such models (d'Alpoim Guedes et al 2016).

\section{Conclusions and Future Directions}

Environmental archaeology is no longer the organic datasets of excavation report appendices but central to the relevance of archaeology's long-term perspective on present and future environmental problems and solutions. The history of Environmental Archaeology illustrates that disciplinary boundaries are permeable, incorporating scientists from other backgrounds into archaeology, and it is now a field through which archaeology can make a tangible contribution to other fields. The adoption of new techniques and integrated analyses suggest that the boundaries of environmental archaeology are expanding and becoming inclusive. Our challenge, however, is to improve communication and not be trapped in ghettos of our own particular methodological worries and specialist terminologies. 


\section{Acknowledgements}

This work was supported by the Comparative Pathways to Agriculture Project

(ComPAg) funded by a European Research Council advanced grant (no.323842) from 2013-2018.

\section{References Cited}

\section{Barton, Huw and Robin Torrence}

2015 "Cooking up recipes for ancient starch: assessing current methodologies and looking to the future" Journal of Archaeological Science 56: 194-201.

DOI: 10.1016/j.jas.2015.02.031

\section{Bevan, Andrew}

2015 "The data deluge" Antiquity 89(348): 1473-1484. DOI:10.15184/aqy.2015.102

Boivin, Nicole et al 2016 "Ecological consequences of human niche construction: Examining long-term anthropogenic shaping of global species distributions". PNAS. DOI:10.1073/pnas.1525200113

d'Alpoim Guedes et al

2016 "Twenty-first century approaches to ancient problems: Climate and society" PNAS DOI:10.1073/pnas.1616188113

Derevenski, J.S.

2001 "Is Human Osteoarchaeology Environmental Archaeology?" In: Environmental Archaeology: Meaning and Purpose. Vol 17: 113-133. Environmental Science and Technology library series. DOI:10.1007/978-94-015-9652-7_14

Downey, Sean S., Emmy Bocaege, Tim Kerig, Kevan Edinborough, and Stephen Shennan 2014 "The Neolithic Demographic Transition in Europe: Correlation with Juvenility Index Supports Interpretation of the Summed Calibrated Radiocarbon Date Probability Distribution (SCDPD) as a Valid Demographic Proxy" PLOS One DOI: 10.1371/journal.pone.0105730

Ellis, Erle et al 2013 "Used planet: a global history" PNAS 110(20): 7978-7985.

DOI:10.1073/pnas.1217241110

Ford, R.I. 2011 "History of Ethnobiology" In Ethnobiology. E. N. Anderson, D. Pearsall, E. Hunn, and N. Turner, eds. Pp. 15-27. New York: Wiley-Blackwell.

Fuller, D.Q 
2008 "Archaeological Science in Field Training". In From Concepts of the Past to Practical Strategies: The Teaching of Archaeological Field Techniques. P.J. Ucko, Ling Qing and Jane Hubert, eds. Pp 183-205. London: Saffron Press.

Izdebski, Adam, et al. 2016 "Realising consilience: How better communication between archaeologists, historians and natural scientists can transform the study of past climate change in the Mediterranean" Quaternary Science Reviews 136:5-22, DOI:10.1016/j.quascirev.2015.10.038

Lyman, R.L. 2012 "Applied Zooarchaeology: History, Value, and Use" In: Conservation Biology and Applied Zooarchaeology. S. Wolverton and R. L. Lyman, eds. Pp 208-232. Tucson: University of Arizona Press.

Minnis, P.E.

2014. New Lives for Ancient and Extinct Crops. Tucson: The University of Arizona Press.

Ruddiman, W.F. 2013 "Bridging a disciplinary gap" In Climates, Landscapes, and Civilizations, L. Goisan, D.Q. Fuller, K. Nicoll, R.K. Flad, P.D. Clift, eds. Pp 1-10. Washington: American Geophysical Union.

Schwagerl, C.

2014. The Anthropocene. The Human Era and How it Shapes our Planet. Santa Fe: Synergistic Press.

Trigger, Bruce, G. 1989 A History of Archaeological Thought. Cambridge University Press, Cambridge. 